\title{
MORPHOMETRICAL STUDY OF THE STINK BUG Apodiphus amygdali (GERMAR) (HEMIPTERA: PENTATOMIDAE) IN IRAQ
}

Sarkawt Hussein Muhammed*

\author{
Riyadh Ahmed Al-Iraqi**
}

*Biology Department, College of Science, University of Salahaddin-Erbil, Iraq

**Biology Department, College of Science, College of Science-University of Mosul, Iraq

\begin{abstract}
The morphological characteristics in association with dimensions of all the stages of $A$. amygdali were studied during season 2007. The egg is barrel in shape, bright green in colour when freshly lay, usually deposited in masses which contain 14 eggs each. The average body lengths and widths of each of the five nymphal instars were: $(2.80,2.22)$; $(4.36,3.22)$; $(6.10,3.94)$; $(10.38,6.01)$ and $(12.40,7.04)$ $\mathrm{mm}$, respectively. The adult measurements were: (14.48) $\mathrm{mm}$ long and (7.60) $\mathrm{mm}$ wide for male and (16.48) $\mathrm{mm}$ long and (8.32) $\mathrm{mm}$ wide for female, the first nymphal instar characterized by shiny orange, the rest instars are grey, while the adult is red to reddish bronze and gray to black.
\end{abstract}

\section{INTRODUCTION}

The fruit trees stink bug $A$. amygdali is one of the pentatomid plant feeding stink bugs, which attacking many of the fruit trees especially plum, apricot, apple, olive, and pear. Furthermore non-fruit trees viz. poplar, pine, planetree, willow bark may also be infested (Muhammed, 1994). Both nymphs and adults feed by sucking the plant sap. Reviewing the literature, the Information available about this pest in the world and in Iraq considered as records on the hosts.

China (1938) recorded $A$. amygdali in Al-Heneidi quarter near Baghdad, and Khalaf (1963) in Erbil city. Hussain (1963) in his provisional list of insect pests and bibliography of insect fauna of Iraq has reported that $A$. amygdali attacks the fruit trees peach, plum and apricot. Swailem et al. (1974) mentioned this insect amongst their list of insect's fauna of Mosul attacking wild plants. Al-Ali (1977) recorded $A$. amygdali in Baghdad, which occupied on peach, plum and apricot. Saad and Amin (1983) indicated that $A$. amygdali attack some fruit trees such as peach, apricot and plum trees in addition to poplar trees in the north Iraq. The aim of the present work is to describe and measurement all the different stages of A. amygdali.

\section{MATERIALS AND METHODS}

The morphological description and measurements of all the stages of A. amygdali were distinct by using a dissecting microscope type Wild Heerbrugg. Descriptions were based on live individuals collected from special cages were made foe rearing the insect on three kinds of fruit trees under the field conditions (Muhammed and Al-Iraqi, 2010) whereas measurements were based on specimens preserved in alcohol 70\% (only for two days). The number of specimens which used for each stage measurement was 27 , measurements done included, length and width of the body, head, scutellum and length of antennal segments.

Part of Ph.D. thesis for the first researcher 2009

Receive date 14/6/2010 accepted 27/10/2010 


\section{RESULTS AND DISCUSSION}

1- Egg stage: The egg is barrel in shape, with an average length of $1.56 \mathrm{~mm}$ and $0.60 \mathrm{~mm}$ in width. The egg is bright green in colour when freshly laid, then turn to yellowish after three or four days, later the two red compound eyes are visible before hatching, indicating its viability. The parasitized eggs usually turn to blackish. In some instances the egg being transparent, incase of no embryo inside. Egg surface (chorion) is smooth (Figure 1). During study the A. amygdali in Baghdad, Yousif (1995) previously found that the female laid the eggs in masses, 11-15 eggs per a mass, and characterized by spherical shape, $2 \mathrm{~mm}$ in diameter, green or pale yellow, and usually lay undersurface of leaves of the olive, pear and fig trees.

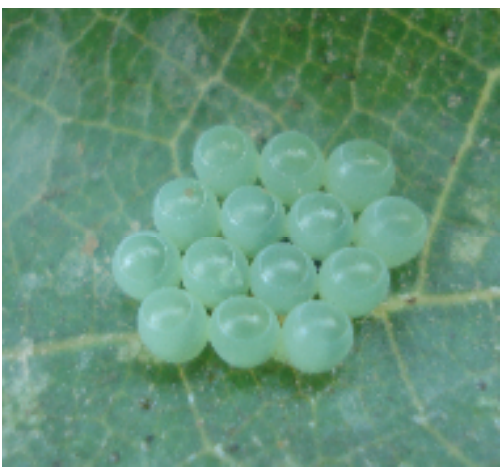

(A)

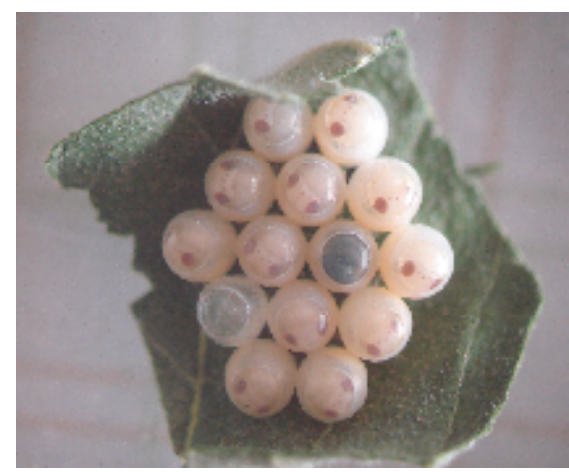

(B)

Figure (1): Egg masses of A. amygdali, (A) New laid eggs (120x); (B) 3 days after laid (120x).

\section{2- Nymphal stage}

2-1 First Nymphal Instar: The body shape is oval with an average of $2.8 \mathrm{~mm}$ length and $2.22 \mathrm{~mm}$ width and the maximum width approach the second abdominal segment. The head posses a pair of filiform antennae, each consists of four segments. Tylus and juga are visible dorsally; the two sessile eyes are spherical and contiguous to anterior margin of the pronotum. The rostrum is reaching to the base of abdomen.

Head: pale yellow or green, tylus and base of head are brown or black. Antennal segments reddish or greenish, except tip of second segment, base and tip of third segment, and base of fourth segment, which are red, rostrum have the same coluors. Pro, meso, and metanotum brown or black. Legs are transparent or pale orange with existing of some dark brown areas. Abdominal segments slightly brown or green, with existing of some irregularly distributed reddish areas. Sternum area are greenish, dorsal and ventral surface connexivum brown or greenish with black spots. Margin of the body are setose. The nymphal color is greenish at the beginning of emergence then converts gradually to orange (Figure 2).

The average length of head was $0.57 \mathrm{~mm}$ while the width was $0.94 \mathrm{~mm}$. The interocular distance was $0.56 \mathrm{~mm}$, antennal segments length were: $0.16,0.40,0.32$, and $0.60 \mathrm{~mm}$ for 1, 2, 3, 4 segments respectively, (Nymphs have 4 antennal segments while adults have 5 antennal segments). 


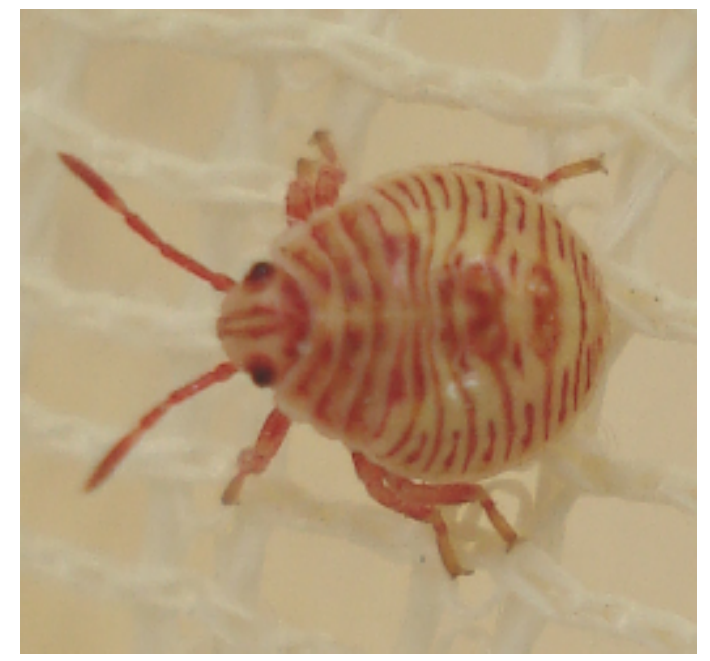

Figure (2): A. amygdali, first nymphal instar (250X)

2-2 Second Nymphal Instar: The body is oval with an average of length $4.36 \mathrm{~mm}$ and $3.22 \mathrm{~mm}$ width, convex, slightly flattened dorso-ventrally. Dorsum of the head, thorax, and abdomen is punctate. Tylus longer than juga, Eyes spherical in shape and slightly separated from pronotum; width through the eyes broader than the width through anterior angles of pronotum; antennal segments and legs are setose (Figure 3).

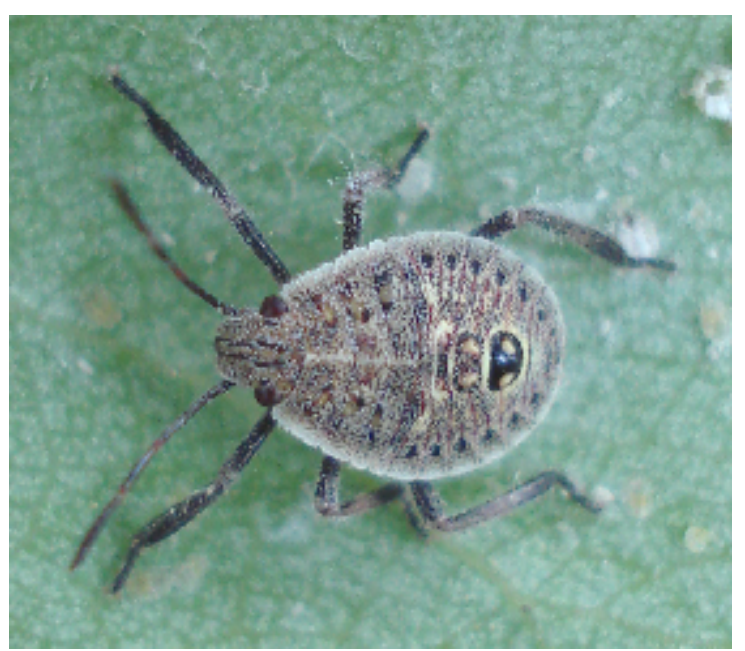

Figure (3): A. amygdali, second nymphal instar (60X)

The setose of the body are white in colour. Head, eyes, antennae, rostrum, legs are black. The lateral sides of the body are white. Antennal segments have some red patchs. Dorsal surfaces of; the head, thorax and abdomen are yellow-brown to gray with some black punctures. The average length of head was $0.92 \mathrm{~mm}$ whereas the average width across the eyes was $1.34 \mathrm{~mm}$ and between the eyes was 0.84 . The lengths of antennal segments were: $0.30,1.12,0.78$, and $1.06 \mathrm{~mm}$ for $1,2,3,4$ segments, respectively. 
2-3 Third Nymphal Instar: The body shape is oval, with an average length 6.10 $\mathrm{mm}$ and $3.94 \mathrm{~mm}$ width, convex and elliptical, ocelli covers with setaceous. The body segmentation is not easily distinguished. The Wings cover the first abdominal segment, and appear as a continuous gray longitudinal band. The abdomen strongly convex dorso-ventrally, with a maximum width at the second abdominal segment.

The body gray in colour and take the colour of the tree trunk of their hosts (mainly apricot, pear and apple trees). The head dark gray with black strips, the eyes are black and well develoed, antennal segments are black with some red patchs. This instr similar to the second instar, but the lateral sides of the body turns to pink with black spots on the dorsal side of the abdomen to be metallic red (Figure 4).

The other body measurements were as follows: head length was $1.16 \mathrm{~mm}$ whereas the width across the eyes was $1.70 \mathrm{~mm}$ and between the eyes was 1.30 . The lengths of antennal segments were: $0.37,1.66,1.12$ and $1.28 \mathrm{~mm}$ for $1,2,3,4$ segments, respectively.

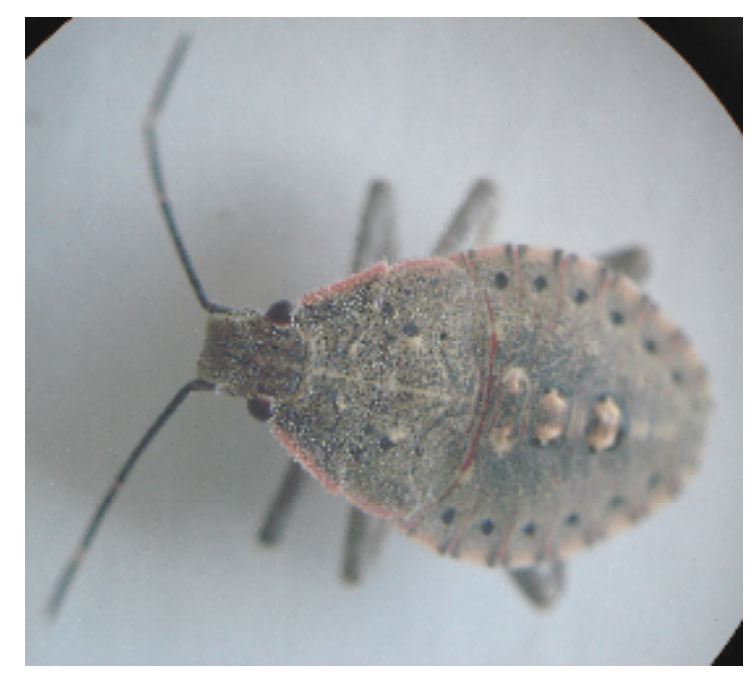

Figure (4): A. amygdali, third nymphal instar (120X)

2-4 Fourth Nymphal Instar: The body is oval, convex, and eliptical, convex dorsally, $10.37 \mathrm{~mm}$ length and $6.01 \mathrm{~mm}$ width. Maximum width at the second abdominal segment, the head is declivitous; ocelli it seen clearly, lateral margin of pronotum flattened; wing pads evident which is wider than long, and reach the second abdominal segment; scutellum reach the base of metanotum. The ventral of abdominal plates is similar to those in the third instar.

The anterior part of the head is setaceous while the posterior devoid. Pale yellow head with brown strips, antennal segments and rostrum are black. Thorax are pink in color, legs pale gray, the tarsus are black, dorsal side of abdomen is gray, while the lateral abdominal segments are pink. The middle spots on the dorsal side of the abdomen turn to yellow (Figure 5).

The average length of the head was: $1.87 \mathrm{~mm}$ whereas the width across the eyes $2.28 \mathrm{~mm}$ and between the eyes 1.45 . The lengths of antennal segments were: $0.54,2.36,1.57$ and $1.66 \mathrm{~mm}$ for $1,2,3,4$ segments, respectively. 


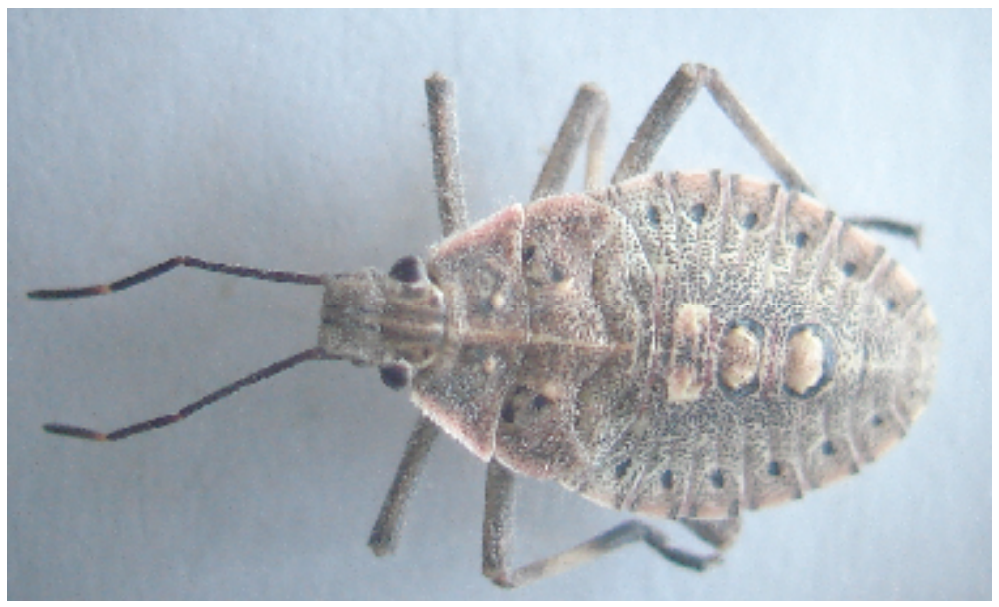

Figure (5): A. amygdali, fourth nymphal instar (63X)

2-5 Fifth Nymphal Instar: The body is oval, $12.40 \mathrm{~mm}$ length and $7.04 \mathrm{~mm}$ width, convex dorsally, and the abdomen slightly concave ventrally. Head well developed ocelli not seen clearly. Wing pads reach the base of fourth abdominal segment. Scutellum is wider than their long and reach the base of third abdominal segment.

Head gray in colour, compound eyes and antennal segments are black, the base of third and fourth segments are orange, the lateral side of first thoracic is pink, legs gray and with some black area. The dorsal side of the abdomen is dark gray and the spots are yellow while the lateral side of the segments is pink (Figure 6).

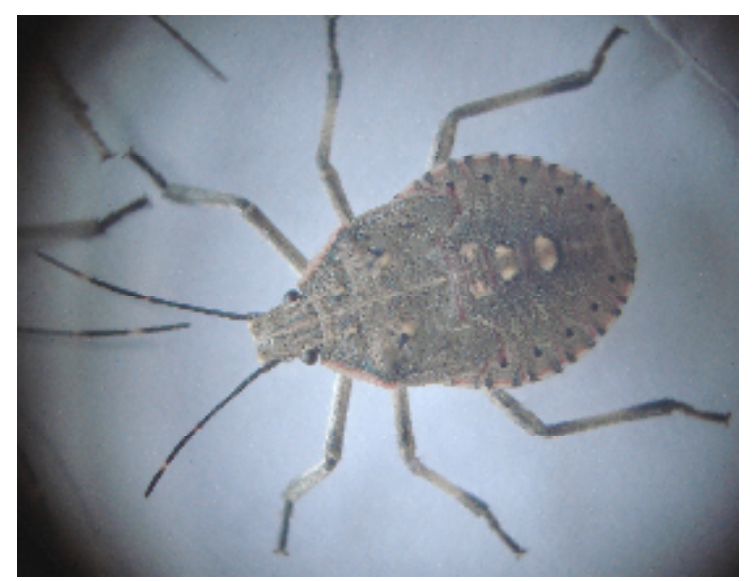

Figure (6): A. amygdali, fifth nymphal instar (60X)

The length of head was $2.0 \mathrm{~mm}$ whereas the width across the eyes was 2.56 $\mathrm{mm}$ and between the eyes was $1.52 \mathrm{~mm}$. The length of antennal segments was: 0.72 , $2.88,1.76$ and $1.92 \mathrm{~mm}$ for $1,2,3,4$ segments respectively.

4-3 Adult stage: The body is oval, convex dorsally, and the abdomen slightly concave ventrally. Anterior margin of juga straight and each jugam gradually rising laterally to form a V-shaped channel at apex, the lateral margins of pronotum markedly sinuate. 
General colour is reddish, brownish or black with dark black spotted. The head is black with orange spotted, there is an orange line inn the middle of head dividing for two parts. Compound ayes are black with an orange color in the base, ocelli are red in color. The antenna is reddish; the base of the fifth segment is pale red.

The thorax and scutellum are orange with black spotted being scattered; the legs are red in color except the black femure. The base of the wing is pale yellow with brown spotted. The connexivum is regularly spotted; middle lightly coloured, orange, red or pink and anterior, posterior ends appear dark spotted, the male being smaller than female.

The average body length of male was: $14.48 \mathrm{~mm}$ while the width was $7.6 \mathrm{~mm}$. Head length was $2.72 \mathrm{~mm}$ whereas the width across the eyes was $2.72 \mathrm{~mm}$ and between the eyes was $1.36 \mathrm{~mm}$. The length of antennal segments: $0.88,1.76,1.92$, 2.00 and $2.08 \mathrm{~mm}$ for $1,2,3,4,5$ segments respectively. The wide of scutellum was 4.44 , while the length was 5.36 (Figure 7).

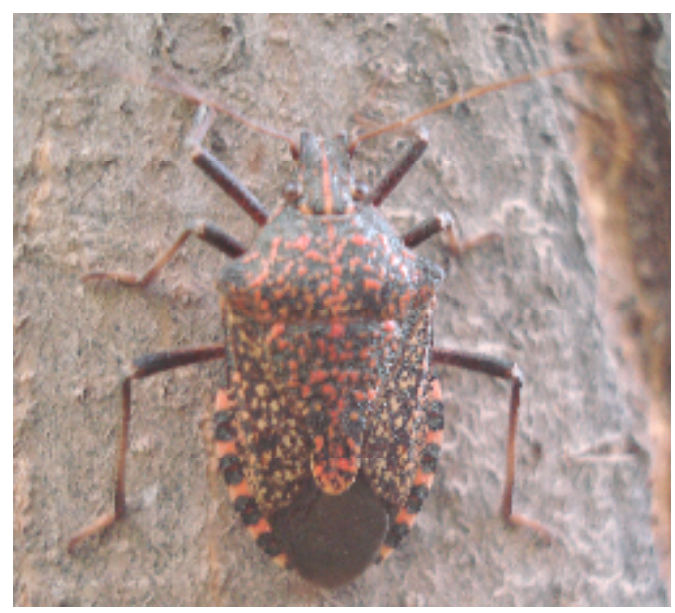

Dorsal view

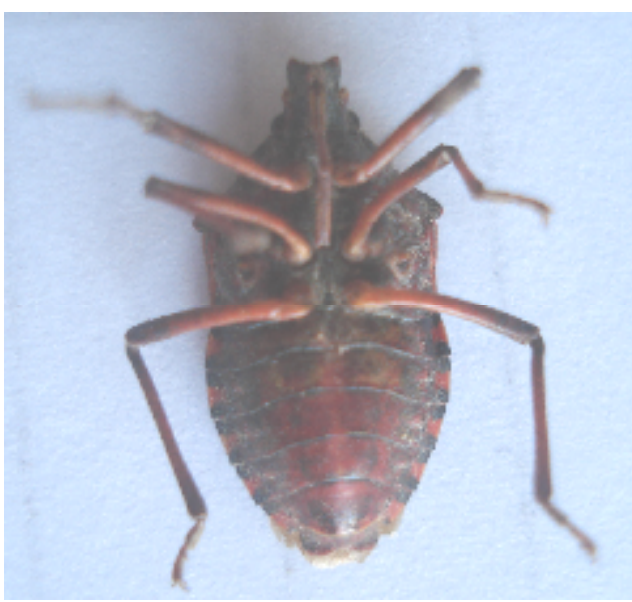

Ventral view

Figure (7): A. amygdali, adult male

Female is similar to male but: the body length was: $16.48-17.60 \mathrm{~mm}$ and the width was $8.32 \mathrm{~mm}$. Head length was 2.64 whereas the width across the eyes was $2.88 \mathrm{~mm}$ and between the eyes was $1.60 \mathrm{~mm}$. The lengths of antennal segments were: $0.92,1.68,2.00,2.08$ and $2.08 \mathrm{~mm}$ for $1,2,3,4,5$ segments respectively. The wide of scutellum was 4.80, while the length was 6.24 (Figure 8).

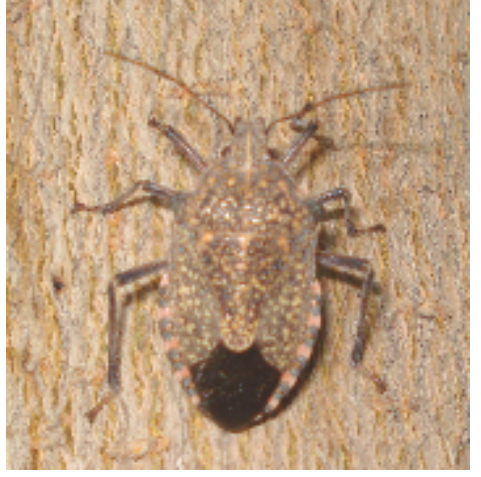

Dorsal view

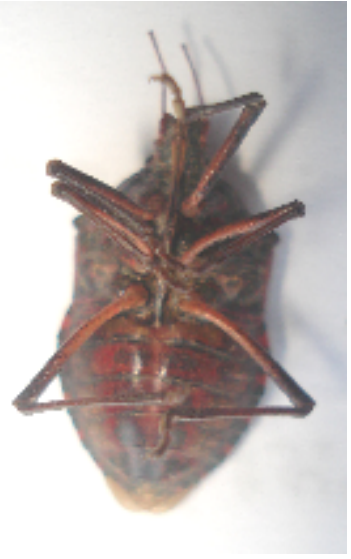

Ventral view

Figure (8): A. amygdali, adult female 


\section{(Hemiptera: Apodiphus amygdali (Germar) دراسة مظهرية قياسية للبق النتن) Pentatomidae)

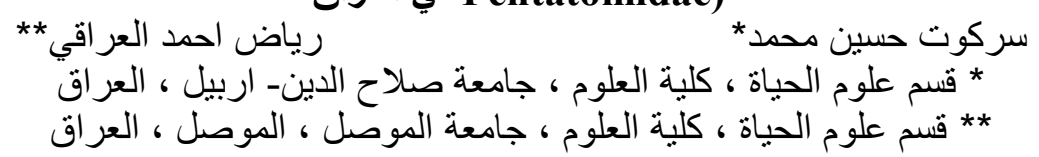

\section{الخلاصة}

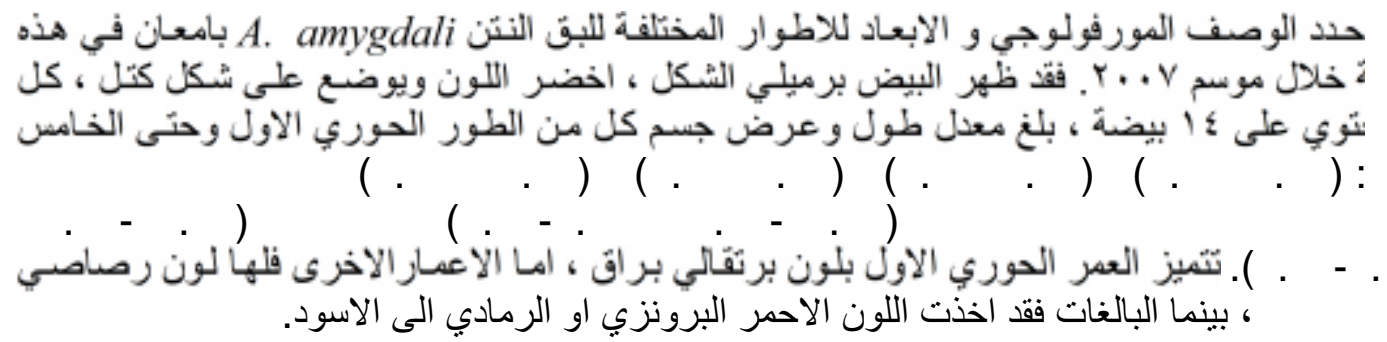

REFERENCES

Al-Ali (1977). Phytophagous and Entomophagous insects and mites of Iraq. Nat. Hist. Res. Center. Pupl. No. 33.

Hussain, A. A. (1963). Provisional list of insect pests and bibliography of insect fauna of Iraq. Bull. Col. Sci. 7:43-83.

Khalaf, K. (1963). Faunastic Notes in Iraq. Bull. Iraq Nat. Hist. Inst. 2(8):1-12.

Muhammed, S. H., (1994). Study of population density of some sap sucking insects on some fruit trees in Erbil. M.Sc. thesis, College of Education, Univesrity of Salahaddin, Erbil, Iraq, 125 P.

Muhammed, S. H. and Riyadh A. Al-Iraqi (2010). The biology of the stink bug Apodiphus amygdali (Germar) (Hemiptera: Pentatomidae). Mesopotamia J. of Agric. 38 (Supplement1), p 53.

Saad, A. H. and A. H. Amin (1983). Economic Insects in Northern of Iraq. Mosul University press. $488 \mathrm{pp}$ (in Arabic)

Swailem, M. S.; A. A. Selim and A. H. Amin (1974). Survey of insect fauna in Hammam Al-Alil, Mosul region, Iraq. Mesop. J. of Agric.130.

Yousif, A. H. (1995). Ecological and biological studies of the fruit tree bark bug Apodiphus amygdali (Germar) (Hemiptera, Pentatomidae). M.Sc. Thesis, University of Baghdad, Iraq. 46 pages. 